\title{
Jerzy Zajadło
}

Uniwersytet Gdański

jzajadlo@prawo.ug.edu.pl

ORCID: https://orcid.org/0000-0002-3113-9828

\section{Rzym, filozofia, prawo}

http://dx.doi.org/10.12775/SIT.2019.0013

Tytuł tego opracowania wskazuje na pewien problem, który jest wprawdzie od dawna znany, ale w ostatnim czasie we współczesnej nauce można zaobserwować wzmożone zainteresowanie kwestią relacji pomiędzy historią starożytnego Rzymu a filozofią oraz filozofią a prawem rzymskim. W tej pierwszej perspektywie rodzi to pytanie zadane tytule pewnej pracy zbiorowej: „filozofia w Rzymie

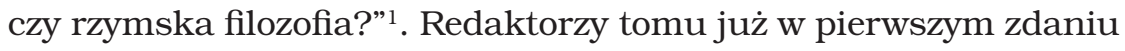
wprowadzenia stawiają trafną hipotezę: „Recepcja filozofii greckiej w Rzymie, wynikająca z ogólnej hellenizacji rzymskiej kultury, była od początku procesem ambiwalentnym", ale ostatecznie dochodzą do wniosku, że „można mówić nie tylko o filozofii w Rzymie, lecz zdecydowanie o rzymskiej filozofii”" ${ }^{2}$. Rzeczywiście, na styku greckich ideałów filozoficznych i rzymskiej praktyki społecznej i politycznej powstał pewien fenomen sui generis.

Podobne zagadnienia napotykamy również w obrębie nauk prawnych. Ciągle trwają bowiem próby odpowiedzi na pytania o różnorodne związki filozofii $z$ prawem rzymskim. Tradycyjnie było to

${ }^{1}$ G.M. Müller, F.M. Zini (Hrsg.), Philosophie in Rom - Römische Philosophie? Kultur-, literatur- und philosophiegeschichtliche Perspektiven, Berlin-Boston 2018.

${ }^{2}$ Ibidem, s. 1 i 40. 
przede wszystkim poszukiwanie (bądź kwestionowanie) ${ }^{3}$ śladów wpływu, jaki recypowana w Rzymie filozofia grecka, zwłaszcza stoicka, wywarła na rzymskie prawo i rzymską jurysprudencję. Pojawiły się jednak także badania nad kierunkiem odwrotnym - jeśli bowiem przyjąć, że istniało coś takiego, jak specyficzna rzymska filozofia, to powstaje pytanie, jaką rolę odgrywało w niej prawo i w jaki sposób wpłynęło ono na dzieła filozoficzne takich postaci jak Cyceron czy Seneka4 . Ostatecznie mamy więc do czynienia $z$ ambiwalencją podobną do tej, która jest udziałem filozofii ogólnej i w związku $\mathrm{z}$ tym natrafiamy na zbliżone, godne bliższej analizy problemy natury merytorycznej i metodologicznej.

Możemy bowiem podobnie ująć to zagadnienie i zapytać zarówno o „prawo w filozofii rzymskiej”, jaki i o „filozofię rzymskich prawników" ${ }^{\prime}$. Z góry można założyć, że dotykamy tutaj znacznie bardziej skomplikowanej kwestii niż w obrębie filozofii ogólnej. W tym przypadku nie chodzi bowiem tylko o zagadnienie eklektyzmu i mniejszej lub większej oryginalności rzymskiej filozofii ogólnej, lecz przede wszystkim o złożone i trudne do rekonstrukcji odpowiedzi na pytania o wzajemną infiltrację prawa i filozofii w obszarze tradycyjnego republikańskiego i klasycznego rzymskiego prawa prywatnego, a także prawa publicznego i karnego. Odpowiedzi na te pytania mają dla nas jednak znaczenie fundamentalne, ponieważ

${ }^{3}$ Zob. np. P.A. Vander Waerdt, Philosophical Influence on Roman Jurisprudence? The Case of Stoicism and Natural Law, w: Aufstieg und Niedergang der römischen Welt, Teil II, Band 36, Teilband 6, Walter De Gruyter, Berlin-New York 1992, s. 4851-4900 oraz J.R. Kroger, The Philosophical Foundations of Roman Law: Aristotle, the Stoics, and Roman Theories of Natural Law, "Wisconsin Law Review" 2004, s. 905-944.

${ }^{4}$ Zob. np. M.T. Griffin, Latin philosophy and Roman law, w: Politeia in Greek and Roman Philosophy, V. Harte, M. Lane (ed.), Cambridge 2013, s. 96-116.

${ }^{5}$ B. Inwood, F.D. Miller, Jr., Law in Roman Philosophy, w: F. D. Miller, Jr., C.-A. Biondi (ed.), A Treatise of Legal Philosophy and General Jurisprudence, vol. 6: A History of the Philosophy of Law from the Ancient Greeks to the Scholastics, 2 wyd., Dordrecht 2015, s. 133-165.

${ }^{6}$ P.G. Stein, The Roman Jurists' Conception of Law, w: A. Padovani, P.G. Stein (ed.), A Treatise of Legal Philosophy and General Jurisprudence, vol. 7: The Jurists' Philosophy of Law from Rome to the Seventeenth Century, Dordrecht 2007, s. $1-30$. 
zarówno dotyczą odległej w czasie historii, jak i nabierają wymiaru paradygmatycznego w kontekście zrozumienia istoty podstawowych elementów naszej współczesnej kultury prawnej ${ }^{7}$. Sprawa nie jest jednak prosta, ponieważ filozofia helleńska nie była homogeniczna i obfitowała w wielość, niekiedy istotnie różniących się od siebie, kierunków (m.in. epikureizm, Nowa Akademia, perypatetyzm, sceptycyzm, stoicyzm) ${ }^{8}$ i nie zawsze łatwo jest ustalić, $z$ którym $z$ nich mamy do czynienia zarówno na linii filozofia $\rightarrow$ prawo, jak i prawo $\rightarrow$ filozofia.

Widać to dobrze na przykładzie pewnych definicyjnych sprzeczności pomiędzy Gaiusem i Ulpianem w początkowych fragmentach justyniańskich Digestów, które od dawna są przedmiotem sporu pomiędzy romanistami. Długo uważano, że tylko tekst Gaiusa jest oryginalny, natomiast ujęcie Ulpiana to efekt późniejszych interpolacji, ale współcześnie odchodzi się raczej od takiego stanowiska. Według jednych te rozbieżności pomiędzy dwoma przedstawicielami klasycznej rzymskiej jurysprudencji nie mają jakiegoś głębszego filozoficznego podłoża ${ }^{9}$, według innych przeciwnie - można je przypisać konkretnym filozoficznym afiliacjom (Gaiusa wpływowi Arystotelesa, a Ulpiana inspiracjom stoikami) ${ }^{10}$. Główny problem sprowadza się do przyjętych przez Gaiusa i Ulpiana podziałów prawa oraz rozumienia istoty prawa natury, ale ma to znaczenie zasadnicze, ponieważ „rozpoczynający Digesta justyniańskie tytuł

7 J.R. Kroger, The Philosophical Foundations, s. 905: "Roman law provides the foundation for numerous legal systems throughout the world, and thus an understanding of Roman law's basic philosophical influences and orientation is essential".

${ }^{8}$ K. Algra, J. Barnes, J. Mansfeld, M. Schofield (ed.), The Cambridge History of Hellenistic Philosophy, Cambridge 1999.

9 Tak. np. P.A. Vander Waerdt, Philosophical Influence on Roman Jurisprudence?, s. 4893: "Our review of the dossier of evidence that might be assembled in support of the widely held hypothesis that Stoic philosophy substantively influenced classical Roman juristic doctrine on ius naturale and related notions has brought us to a negative verdict on this hypothesis".

${ }^{10}$ Tak np. J.R. Kroger, The Philosophical Foundations, s. 906: "Gaius' philosophical views on law, I suggest, are Aristotelian in character. Ulpian's account, in contrast, reflects Greek Stoic influences". 
De iustitia et iure stanowi klucz do zrozumienia podstaw rzymskiej jurysprudencji" ${ }^{11}$.

Gaius przyjmuje podział dychotomiczny i tak wyjaśnia istotę ius civile i ius gentium: „Wszystkie ludy, które rządzą się ustawami i zwyczajami, posługują się częściowo swoim własnym prawem, a częściowo prawem wspólnym wszystkim ludziom. To prawo, które każdy lud ustanowił dla siebie, jest jego własnym prawem i nosi nazwę ius civile, jakby własne prawo społeczeństwa: to natomiast, co naturalny rozsądek ustanowił wśród ludzi, jest wśród wszystkich na równi strzeżone i nazywane ius gentium, czyli prawem, którym posługują się wszystkie narody" (Digesta 1, 1, 9). Jak widać, Gaius nie stosuje wprawdzie terminu ius naturale, ale to nie oznacza, że nie uwzględnia go w swoim podziale - tę rolę odgrywa u niego pojęcie naturalis ratio ${ }^{12}$ stanowiące podstawę ius gentium. To jednak różni go w sposób zasadniczy od Ulpiana, który swoją koncepcję opiera na triadzie ius civile - ius gentium - ius naturale, a naturalis ratio nabiera szerszego wymiaru: „Są dwa działy nauki prawa: publiczne i prywatne. Prawem publicznym jest to, co dotyczy pomyślności państwa rzymskiego, prywatnym zaś to, co dotyczy korzyści jednostek: niektóre sprawy są bowiem pożyteczne dla państwa, inne dla osób prywatnych. Prawo publiczne składa się z prawa sakralnego, prawa dotyczącego kapłanów oraz urzędników. Prawo prywatne dzieli się na trzy części: tworzą je zasady prawa naturalnego, ius gentium oraz ius civile.

Prawem naturalnym jest to, czego natura nauczyła wszystkie istoty żywe: prawo to nie przynależy bowiem jedynie rodzajowi ludzkiemu, lecz wspólne jest wszystkim istotom żywym, które rodzą się na ziemi, w morzu oraz ptakom. $Z$ niego wywodzi się związek męża i żony, który my nazywamy małżeństwem, płodzenie potomstwa, wychowanie: widzimy bowiem, że słusznie uważa się, iż inne istoty żywe, również dzikie, znają to prawo.

${ }^{11}$ A. Tarwacka, O sprawiedliwości i prawie. 1 tytuł 1 księgi Digestów. Tekst tłumaczenie - komentarz, „Zeszyty Prawnicze UKSW” 2003, t. 3, nr 2, s. 357.

12 O tej kategorii J. Koschenbahr-Łyskowski, Ratio naturalis $w$ prawie rzymskiem klasycznem, Warszawa 1930 - autor zwraca jednak uwagę, że ratio na- 
Ius gentium jest to prawo, którym posługują się narody ludzkie. Łatwo jest odróżnić je od prawa naturalnego, bowiem pierwsze jest wspólne wszystkim istotom żywym, drugie zaś jedynie ludziom” (Digesta 1, 1, 1, 2-4).

Różnica pomiędzy Gaiusem i Ulpianem jest zasadnicza - o ile bowiem ten pierwszy łączy ius naturale wyłącznie ze światem ludzi, o tyle ten drugi rozciąga go na wszystkie istoty żyjące.

W zrozumieniu opisywanego tutaj procesu wzajemnej infiltracji pomiędzy filozofią i jurysprudencją kluczową postacią wydaje się jednak Cyceron. Choć nie ulega wątpliwości, że był on przede wszystkim filozofem ${ }^{13}$ i że prawo odgrywało niebagatelną rolę w jego pismach z zakresu filozofii politycznej (De re publica, De legibus) oraz w jakiejś mierze etyki (De finibus bonorum et malorum, De officiis), a także w licznych mowach politycznych i sądowych ${ }^{14}$, to ciągle aktualne pozostaje pytanie, czy i w jakim stopniu Arpinata był także prawnikiem w rzymskim rozumieniu tego pojęcia ${ }^{15}$. Sprawę dodatkowo komplikuje fakt, że poglądy Cycerona nie są jednoznaczne pod względem filozoficznych afiliacji, widać w nich wpływy Platona, Arystotelesa, Nowej Akademii, epikureizmu, sceptycyzmu, stoicyzmu etc., słowem - są bardzo eklektyczne. Najczęściej skłonni jesteśmy kojarzyć myśl Cycerona ze stoicyzmem, co wydaje się uzasadnione w odniesieniu do wielu jego koncepcji etyczno-prawnych, ale chyba nie oddaje istoty myśli tego filozofa jako całości - we współczesnej literaturze określa się go więc raczej mianem rzymskiego sceptyka ${ }^{16}$.

Współczesne interpretacje wyraźnie odbiegają jednak od wyjątkowo krytycznych i deprecjonujących dorobek Cycerona ocen z przełomu XIX i XX w., zapoczątkowanych przez słynnego historyka

turalis mogło być wprawdzie synonimem ius naturale, ale mogło też oznaczać pewien typ rozumowania prawniczego ex rerum natura.

13 Szeroko na ten temat J.G.E. Powell (ed.), Cicero: The Philosopher. Twelve Papers, New York 1995 (reprinted 2002).

14 J. Harries, The law in Cicero's writings, w: The Cambridge Companion to Cicero, C. Steel (ed.), Cambridge 2013, s. 107-121.

15 J. Zajadło, Czy Cyceron był prawnikiem?, „Palestra” 2018, nr 11, s. 32-38.

${ }^{16}$ R. Woolf, Cicero. The Philosophy of a Roman Sceptic, London-New York 2015 . 
Theodora Mommsena, następnie kontynuowanych w ramach tzw. Quellenforschung ${ }^{17}$. Współcześni badacze nie kwestionują wprawdzie eklektyzmu Arpinaty, ale starają się raczej wyeksponować wszechstronność, oryginalność i aktualność myśli Cycerona wynikającą z twórczego zaadaptowania greckich konstrukcji teoretycznych do rzymskiej praktyki. Warto jednak przy okazji podkreślić, że taką ocenę już wcześniej w polskiej literaturze przedmiotu zaproponował Kazimierz Kumaniecki: „Cyceron na pewno nie miał ani ambicji, ani zamiaru stworzyć nowego, oryginalnego systemu filozoficznego. Żył w epoce eklektyzmu [...]. Praktyka eklektyków nie była jednak pozbawiona oryginalności, polegającej właśnie na przyjmowaniu pewnych tez, a odrzucaniu innych. W ten sposób powstawały nowe zespoły myślowe zabarwione indywidualnością ich twórców [...]. Można powiedzieć, chyba bez przesady, że niemal wszystko, co pisze [Cyceron - J. Z.], zmienia się pod jego piórem i z greckiego staje się rzymskie. Objawia się to nie tylko w sposób zewnętrzny, w niezwykle częstym egzemplifikowaniu głoszonych tez przykładami zaczerpniętymi z życia i historii rzymskiej i nie tylko w scenerii czysto rzymskiej, w jakiej odbywają się jego dialogi. Rzymski element sięga znacznie głębiej, a myśli greckie stale konfrontowane są $z$ aktualną sytuacja rzymską [...]. Zestawienie mądrości Greków z mądrością "dawnych Rzymian", konfrontacja myśli filozoficznej greckiej z tradycją i rzeczywistością rzymską przewijają się niemal we wszystkich dziełach filozoficznych Cycerona. Są rezultatem nie tylko wytężonej lektury dzieł Greków, lecz także doświadczenia życiowego ich twórcy i przywiązania do tradycji starorzymskiej. Dlatego też są żywe i dlatego tak wielki wpływ mogły wywierać na potomnych" ${ }^{18}$.

Z kilku względów pisanie o postaci Cycerona i jego myśli nie jest współcześnie zadaniem łatwym:

17 Różne oceny Cycerona i jego dorobku na przestrzeni dziejów świetnie przedstawił, w klasycznej już dzisiaj monografii z 1897 r., T. Zieliński, Cicero im Wandel der Jahrhunderte, Wiesbaden 1912.

${ }^{18}$ K. Kumaniecki, Literatura rzymska. Okres cyceroński, Warszawa 1977, s. 3 23 i n.; podobne opinie wyraził ten autor także w swojej znakomitej biografii Cyceron i jego wspótcześni, Warszawa 1989 (1 wyd. - 1959). 
1. Mamy do czynienia $z$ ogromnym i różnorodnym dorobkiem obejmującym pisma filozoficzne, historyczne, literackie i retoryczne oraz mowy polityczne i sądowe, a także liczną korespondencję.

2. Wprawdzie poważna część $\mathrm{z}$ tego dorobku przetrwała do naszych czasów, ale część zaginęła i musimy odtwarzać jego treść na podstawie źródeł pośrednich, co zmusza nas do bardziej lub mniej uprawnionych spekulacji interpretacyjnych.

3. Każdy powyższych elementów ma $z$ jednej strony charakter odrębny, z drugiej jednak ściśle wiąże się z pozostałymi, co wymaga od badacza znajomości całości tej spuścizny.

4. Różne role Cycerona, jako polityka, urzędnika, senatora, filozofa, retora, oratora, poety, historyka, adwokata etc., są głęboko wplecione w dramatyczną historię polityczną, prawną i społeczną Rzymu z końca okresu republikańskiego i bez znajomości tego tła jego dzieła trudno w sposób właściwy zrozumieć.

5. Dawna i współczesna literatura na temat Cycerona i jego myśli jest tak ogromna, że można by nią wypełnić sporych rozmiarów bibliotekę.

6. Towarzyszą temu bardzo różnorodne, niekiedy wręcz skrajne, interpretacje i oceny zarówno poszczególnych elementów tego dorobku, jak i postaci Cycerona oraz jego dzieła jako całości od fascynacji wyjątkowo umiejętnym połączeniem greckiej filozofii $z$ rzymskim pragmatyzmem politycznym po zarzuty mało twórczego eklektyzmu i odmówienie mu jakiejkolwiek intelektualnej oryginalności.

Na kolumnach otaczających budynek Sądu Najwyższego w Warszawie umieszczono 86 łacińskich inskrypcji - zdecydowana większość z nich pochodzi z Digestów Justyniana, a więc ich autorami byli rzymscy prawnicy, głównie $z$ okresu klasycznego. Niektóre $z$ tych sentencji (regulae iuris) ${ }^{19}$ zaczerpnięto jednak $z$ innych źródeł, a wśród nich aż sześć paremii to znane myśli Cycerona $z$ jego dzieł filozoficznych i mów procesowych. Słynny rzymski filozof, orator

19 W. Wołodkiewicz (red.), Regulae iuris. Eacińskie inskrypcje na kolumnach Sądu Najwyższego Rzeczypospolitej Polskiej, Warszawa 2010. 
i polityk był rzeczywiście prawdziwym mistrzem języka łacińskiego i miał wyjątkowy dar tak syntetycznego i sugestywnego formułowania swoich wypowiedzi, że już dawno oderwały się one od swojego historycznego kontekstu i do naszych czasów przetrwały jako uniwersalne i ponadczasowe mądrości. Część z sentencji na kolumnach wokół budynku Sądu Najwyższego ma charakter techniczny i te należą do typowego warsztatu prawniczego (np. reguła kolizyjna lex posteriori derogat legi priori), ale większość niesie ze sobą głębokie przesłanie filozoficzne, moralne czy polityczne. Dotyczy to w szczególności tych, których autorem był właśnie Cyceron: Summum ius summa iniuria oraz Cedant arma togae z traktatu O powinnościach (De officiis 1, 33 i 1, 77), Legem bonam a mala nulla alia nisi naturae norma dividere possumus oraz Salis populi suprema lex esto z dialogu O prawach (De legibus 1, 44 i 3, 8), Quid est enim civitas nisi iuris societas civium $\mathrm{z}$ dialogu $O$ państwie (De republica 1,49 ) i wreszcie Silent leges inter arma z oracji Pro Milone $(4,11)$.

We współczesnych zbiorach można odnaleźć kilkaset paremii i zwrotów Cycerona, które dotyczą bardzo różnych dziedzin - od historii i retoryki przez etykę i politykę aż po językoznawstwo i religię ${ }^{20}$, ale tylko kilkadziesiąt $z$ nich bezpośrednio lub pośrednio odnosi się do prawa i prawoznawstwa ${ }^{21}$. Te proporcje mogą rzeczywiście potwierdzać zasadność postawionego wyżej pytania: czy Cyceron był prawnikiem? Wprawdzie fakt, że niektóre jego słynne powiedzenia umieszczono na kolumnach budynku Sądu Najwyższego w Warszawie, mógłby świadczyć o ich ogromnym znaczeniu dla prawa oraz prawników i z pozoru powinien rozwiewać wszelkie wątpliwości, ale rzecz wydaje się znacznie bardziej złożona. Dla przykładu - w tytule niewielkiej, ale bardzo znanej biografii Cycerona pióra Winfrieda Stroha w odniesieniu do rzymskiego myśliciela

20 Zob. np. Cz. Michalunio SJ, Dicta editio maior. Zbiór łacińskich sentencji, przysłów, zwrotów, powiedzeń, Kraków 2008; bardzo bogatą antologię najbardziej znanych cytatów z Cycerona stworzyli H. Taylor i M.L. Taylor Hunt, The Sayings of Cicero, w: H. Taylor, Cicero. A Sketch of His Life and Works, Chicago 1916, s. 459-603.

${ }^{21}$ Zob. np. K. Burczak, A. Dembiński, M. Jońca, Łacińskie sentencje i powiedzenia prawnicze, Warszawa 2018. 
pojawiają się pojęcia mówcy, męża stanu czy filozofa, ale ani słowa o prawniku. Kiedy jednak sięgniemy do książki, znajdziemy tam takie zmuszające do zastanowienia zdanie: „Nawet jeśli [Cyceron] nie był "jurystą", to był jednak prawniczym myślicielem [wielkiego] formatu"22. Wszystko zależy od perspektywy spojrzenia - czy ma być to perspektywa historyczna, uwzględniająca specyficzne rzymskie realia $z$ przełomu II i I w. p.n.e, czy raczej perspektywa współczesna, uznająca paremie Cycerona za pewne ponadczasowe dziedzictwo kulturowe obejmujące swoim zasięgiem wprawdzie nie tylko, lecz także szeroko pojęte prawoznawstwo, i dostrzegająca, że „twórczość Cycerona oprócz olbrzymich wartości literackich, humanistycznych, historycznych jest ponadto niewyczerpanym źródłem przekazów z zakresu prawa" 23 .

Już na wstępie możemy więc postawić dwie hipotezy, które będą przedmiotem naszych dalszych rozważań. W perspektywie historycznej Cyceron nie był przede wszystkim prawnikiem w tym znaczeniu, w jakim dzisiaj mówimy o rzymskiej późnorepublikańskiej, a następnie klasycznej i poklasycznej jurysprudencji (iuris consultus), był natomiast adwokatem (advocatus) w specyficznym, rzymskim sensie tego pojęcia ${ }^{24}$. Paradoks polegał na tym, że wykonywanie funkcji adwokata nie wymagało koniecznie wiedzy prawniczej, chociaż akurat Cyceron łączył oba te elementy. Z kolei w perspektywie współczesnej nie wahalibyśmy się przed nazwaniem go prawnikiem, ponieważ inaczej pojmujemy sens słowa iurisprudentia, utożsamiając je niekiedy albo $z$ prawoznawstwem in genere, albo $z$ teorią i filozofią prawa in specie ${ }^{25}$. Nawet jeśli Cyceron jest obecnie kojarzony przede wszystkim z filozofią polityki, m.in. za sprawą swojego dzieła O państwie (De republica), to pamiętajmy, że uchodzi także za autora pierwszego w dziejach systemu filozoficzno-prawnego, sformułowa-

${ }^{22}$ W. Stroh, Cicero. Redner, Staatsmann, Philosoph, München 2008, s. 24.

${ }^{23}$ J. Kamiński, Cicero, w: Prawo rzymskie. Stownik encyklopedyczny, red. W. Wołodkiewicz, Warszawa 1986, s. 161.

${ }^{24}$ Szerzej o tym J.A. Crook, Legal Advocacy in the Roman World, Ithaca-New York 1995.

${ }^{25}$ Ł. Pikuła, Iurisprudentia, w: Leksykon tradycji rzymskiego prawa prywatnego, red. A. Debiński, M. Jońca, Warszawa 2016, s. 198 i n. 
nego w dialogu $O$ prawach (De legibus) ${ }^{26}$, a niektórzy uważają go wręcz za pierwszego w historii prawdziwego filozofa prawa ${ }^{27}$. Stworzył więc pewną swoją własną - po części eklektyczną, po części oryginalną $^{28}$ - filozofię prawa o ponadczasowym i uniwersalnym charakterze, która po dzień dzisiejszy inspiruje badaczy ${ }^{29}$. Czy i na ile ta filozofia prawa Cycerona wpłynęła na kształt rzymskiej jurysprudencji, a zwłaszcza na rozumienie konkretnych instytucji prawnych przez rzymskich prawników okresu klasycznego, to już zupełnie inne zagadnienie.

Przy pomocy pewnej gry słów charakteryzuje się niekiedy współczesnych filozofów prawa, np. Gustawa Radbrucha - był nie tylko prawnikiem, lecz także filozofem, politykiem i humanistą ${ }^{30}$. Z Cyceronem jest jakby odwrotnie - był nie tylko filozofem, retorem, oratorem i politykiem, lecz być może także prawnikiem. Takie fenomeny zdarzają się jednak także współcześnie, i to również na naszym gruncie - podobnie moglibyśmy powiedzieć np. o Czesławie Znamierowskim: przedmiotem jego zainteresowania była nie tylko filozofia, socjologia, psychologia czy ekonomia, lecz także, nawet jeśli z pozoru tylko subsydiarnie, prawoznawstwo par excellence ${ }^{31}$. Nawet więcej, oceniając jego cały dorobek naukowy, musimy stwierdzić, że ten teoretyczno- i filozoficzno-prawny okazał się z jednej strony najbardziej trwały i ponadczasowy, z drugiej zaś najbardziej aktualny i uniwersalny. Pozostając w kręgu tych dwóch przykładów, można stwierdzić, że Radbruch, uznawany przecież za filozofa prawa, nigdy nie studiował filozofii, natomiast Znamierowski studiował przede

${ }^{26}$ H. Waśkiewicz, „De legibus” Cicerona - pierwszy $w$ dziejach myśli europejskiej system filozoficzno-prawny, „Roczniki Filozoficzne KUL” 1960, t. 8, nr 2, s. 39-52.

${ }^{27}$ F.H. Llano Alonso, Cicero and Natural Law, "Archiv für Rechts- und Sozialphilosophie” 2012, vol. 98, no. 2, s. 157-168.

${ }^{28}$ D.H. van Zyl, Cicero's Eclecticism and Orgiinality, "Akroterion - Journal for the Classics in South Africa” 1990, vol. 35, no. 3-4, s. 118-122.

${ }^{29}$ Z nowszej literatury por. np. P.J. du Plessis (ed.), Cicero's Law. Rethinking Roman Law of the Late Republic, Edinburgh 2016.

${ }^{30}$ J. Zajadło, Dziedzictwo przeszłości. Gustaw Radbruch: portret filozofa, prawnika, polityka i humanisty, Gdańsk 2007.

${ }^{31}$ J. Zajadło, Czesław Znamierowski - uczony transcendentny, „Państwo i Prawo" 2018, nr 11, s. 66-76. 
wszystkim filozofię, a studia prawnicze były tylko uzupełnieniem tej edukacji. Stąd i zasadnicza różnica - Radbruch nadbudowywał swoją filozofię prawa nad szczegółowymi dogmatykami prawniczymi (zwłaszcza prawem karnym), z kolei Znamierowski nigdy nie zajmował się żadną dogmatyką prawniczą, patrzył na dogmatyki $z$ lotu ptaka i w filozofii prawa widział przede wszystkim budowanie metodologicznych postaw całego prawoznawstwa. $Z$ Cyceronem na gruncie tych egzemplifikacji było jeszcze inaczej - na początku swojej kariery pobierał nauki u rzymskich jurystów oraz greckich filozofów i retorów, później w jakimś stopniu wykorzystywał swoją wiedzę prawniczą i retoryczną jako advocatus i wprawdzie nigdy nie wcielił się w rolę typowego iurisconsultus, to jednak u schyłku życia pisał dzieła filozoficzne i retoryczne, w których prawo odgrywa niepoślednią rolę, ale głównie w wymiarze filozoficznym, a nie dogmatycznym $^{32}$. Dodajmy też, że jako młody człowiek wiedzę prawniczą oraz filozoficzną i retoryczną zdobywał u nie byle kogo: tę pierwszą u Kwintusa Mucjusza Scewoli Augura, a po jego śmierci u Kwintusa Mucjusza Scewoli Pontifeksa; tę drugą w Rzymie i w Grecji od m.in. ${ }^{33}$ Filona $z$ Laryssy, Antiocha $z$ Askalonu, stoika Posejdonisa czy retora Molona.

Zacznijmy od perspektywy historycznej i hipotezy, że prawnikiem w rzymskim znaczeniu Cyceron jednak nie był, chociaż doskonale wiedział, na czym polega rola jurysty. W traktacie $O$ mówcy (De oratore I, 48, 212) sam pisał o trzech rodzajach takiej działalności: respondere, cavere i agere. Pierwsza oznaczała udzielanie porad prawnych, druga to układanie formuł procesowych i aktów prawnych, trzecia wreszcie to udział w procesie $\mathrm{w}$ charakterze pomocnika strony ${ }^{34}$. Pamiętajmy jednak, że wszystko to dotyczyło prawa prywatnego i w tym znaczeniu taką działalnością Cyceron raczej się nie zajmował, jego domeną było bardziej prawo publiczne, w tym prawo karne $z$ całą jego rzymską specyfiką.

${ }^{32}$ Bardzo przekonywająco na ten temat Z. Lučić, Cicero als Jurist und Theoretiker, „Annales FLB - Belgrad Law Review” 2010, year LVIII, no. 3, s. 137-150.

33 Okres studiów prawniczych i filozoficznych Cycerona omawia szeroko K. Kumaniecki, Cyceron, s. 48-67 i 82-95.

${ }^{34}$ W. Litewski, Jurysprudencja rzymska, Kraków 2000, s. 19 i n. 
Nie przez przypadek rzymskich prawników określano różnymi terminami: iuris prudentes, iuris periti, iuris consulti, iuris studiosi, iuris auctores czy iuris conditores. Te pojęcia wskazują wprawdzie na różne aspekty ich działalności, ale potraktowane łącznie oznaczały trzy istotne rzeczy: po pierwsze, konieczność znajomości prawa; po drugie, praktyczne wykorzystywanie tej wiedzy; po trzecie, określony wysoki poziom obu tych elementów (stąd podrzędni prawnicy, określani terminem pragmatici, nie byli uważani za iuris prudentes) ${ }^{35}$. Wszystko wskazuje na to, że stosowną wiedzę i poziom Cyceron z pewnością posiadał, jednak raczej nie stosował ich praktycznie w charakterystycznych dla rzymskich prawników formach polegających na respondere, cavere et agere. Nawet jeśli miał niezbędne ku temu kwalifikacje, to w pewnym momencie życia zdecydował się na wykonywanie innych funkcji publicznych (polityka, oratora, retora i wreszcie filozofa) i w związku z tym nie był to wybór kariery prawniczej w rzymskim rozumieniu tego pojęcia ${ }^{36}$.

Nie oznacza to jednak, że ta sfera była mu całkowicie obca prowadził pewne sprawy cywilne, i to $z$ sukcesem. Miał również w tym zakresie pewne ambicje naukowe: wiemy przecież o traktacie (zaginionym lub jedynie planowanym) De iure civile in artem redigendo (ok. 55 r. p.n.e), o którym wspomina w Brutusie i De oratore - to projekt uporządkowania ius civile na wzór sztuki (ars), ale w znaczeniu praktycznej umiejętności przeciwstawionej czystej teorii (grecka techne) ${ }^{37}$. W Oratio pro Aulo Caecina nie tylko potwierdził swoją wiedzę z zakresu rzymskiego prawa prywatnego, lecz także dowiódł pewnych szczególnych, wykraczających poza epokę, zdolności interpretacyjnych na miarę, mutatis mutandis, współczesnej filozofii języka i analitycznej teorii prawa. Nie jest więc tak, że Cyceron całkowicie lekceważył jurysprudencję, jako advocatus traktował ją jednak subsydiarnie i wtórnie w stosunku

${ }^{35}$ Idem, Podstawowe wartości prawa rzymskiego, Kraków 2001, s. 27 i n.

${ }^{36}$ Z. Lučić, Cicero als Jurist, s. 143: „Er war zwar kein Jurist im Sinne einer Profession, obwohl er sich selbst oft als solcher definierte (De oratore 1.48.212). Aber vieles deutet darauf hin, dass er ein ausgesprochener Kenner des Rechts war".

${ }^{37}$ H. Honsell, Th. Mayer-Maly, Rechtswissenschaft. Eine Einführung in das Recht und seine Grundlagen, Berlin-Heidelberg 2015, s. 26 i n. oraz 138. 
do kompetencji retorycznych. W perspektywie historycznej ostatecznej oceny fenomenu „Cyceron prawnik” nie ułatwia nam też sam zainteresowany. Wprawdzie „nigdzie jurysprudencja nie była tak szanowana jak w Rzymie"38, ale we wspomnianym wyżej traktacie O mówcy (De oratore) można spotkać różne opinie o jurystach raz są z pewnym sarkazmem i ironią krytykowani za formalizm, drobiazgowość i brak retorycznego polotu, w innych miejscach autor odnosi się do nich z szacunkiem i uznaniem. Jednak „krytykę mówcy Cycerona należy oceniać w konkretnych kontekstach, zwłaszcza w związku z jego adwokacką działalnością. Dotyczy to w szczególności mowy Cycerona Pro Murena, w której występował przeciw juryście Serviusowi”39. Rzeczywiście, niektóre fragmenty tej słynnej oracji mogą wprawiać prawników w pewną konsternację i zakłopotanie lub wręcz zażenowanie, ponieważ Cyceron, stosując różne style retoryczne, kpi sobie $z$ formalizmu rzymskich jurystów, stawia retorykę wysoko ponad jurysprudencję i deklaruje, że wiedzę prawniczą może posiąść zaledwie w parę dni. Nie była to chyba jednak jego rzeczywista ocena jurysprudencji, lecz raczej pewna taktyka procesowa hic et nunc, niepozbawiona sarkazmu, ironii i żartobliwej złośliwości, na którą mógł sobie pozwolić bez większej szkody, ponieważ przeciwnikiem procesowym był jego bliski przyjaciel, wybitny prawnik Servius Sulpicius Rufus ${ }^{40}$.

Niemniej w oratio pro Murena pewne słowa pod adresem jurystów i jurysprudencji padły i w związku z tym warto je tutaj zacytować. Cyceron kpi sobie bowiem ze swojego przeciwnika procesowego i stara się wykazać, jak mało pożytku przynosi jego działalność w porównaniu $\mathrm{z}$ jednej strony $\mathrm{z}$ dowódcą wojskowym, $\mathrm{z}$ drugiej zaś z mówcą: „Nie uchodzi za trudną nauka, która zawarta jest w kilku przepisach nie wymagających żadnego objaśnienia. Toteż, jeśli mnie rozgniewacie, obiecam wam, że za trzy dni zostanę biegłym prawnikiem, chociaż jestem mocno zajęty [...]. Toteż nie tylko sławę

${ }^{38}$ W. Litewski, Jurysprudencja, s. 10.

39 Ibidem, s. 11; szeroko na temat relacji Cyceron-rzymscy juryści zob. J. Harries, Cicero and the Jurists. From Citizens' Law to the Lawful State, London 2006.

${ }^{40}$ K. Kumaniecki, Cyceron, s. 205 i n. 
wojenną należy stawiać wyżej od waszych formułek; także biegłość w mówieniu o wiele większą ma wartość przy ubieganiu się o urząd niż te wasze ćwiczenia. Dlatego wielu obywateli, jak mi się zdaje, znacznie chętniej parało się najpierw wymową, i dopiero gdy na tym polu nie osiągnęli żadnych wyników, zwrócili się, idąc po linii najmniejszego oporu, do prawa. Powiadają, że wśród greckich artystów fletnistami zostają muzycy, którym nie powiodło się z kitarą; podobnie u nas widzimy, jak na prawo przerzucają się ludzie, którzy nie mogli się wybić jako mówcy. Wymowa wymaga wielkiego nakładu pracy, niełatwe to zajęcie, ale zaszczytne i zapewniające popularność w szerokich kołach. Od was bowiem domagają się rozsądnej rady dotyczącej danej sprawy, od mówców - samego rozsądku. Wreszcie wasze odpowiedzi i postanowienia bywają często obalane przez mówcę i bez obrony z jego strony nie mogą się ostać" 41 .

Podział ról pomiędzy jurystów i adwokatów miał więc, jak się wydaje, znaczenie decydujące. To nie retoryka i filozofia odstręczały Cycerona od funkcji iuris consultus mimo posiadanej wiedzy prawniczej, była to raczej kwestia osobowości, mentalności i temperamentu. W końcu dwa wieki później Ulpian, jak widzieliśmy, nasycił głęboko swoje wypowiedzi o różnych aspektach prawa treściami filozoficznymi, zwłaszcza stoickimi, a przecież nie przeszkodziło mu to w osiągnięciu sławy jednego $z$ najwybitniejszych rzymskich jurystów w klasycznym tego słowa znaczeniu ${ }^{42}$. Rezygnacja $z$ kariery prawniczej wydaje się więc wyborem całkowicie świadomym i zdeterminowanym osobowością Cycerona - bliżej mu było do sztuki skutecznego przekonywania niż do wiedzy o sformalizowanych prawniczych formułkach. Nic więc dziwnego, że próżno szukać jego imienia wśród najwybitniejszych rzymskich prawników ${ }^{43}$.

Tutaj nasuwa się jednak kolejna analogia pomiędzy Cyceronem i Radbruchem - obaj z woli swoich ojców mieli zdobyć praktyczną

${ }^{41}$ Cyceron, Mowy, Kęty 2003, s. 90 i n.

42 Szerzej o życiu i dziele Ulpiana T. Honoré, Ulpian. Pioneer of Human Rights, Oxford 2002; o pewnych podobieństw w sposobie rozumowania i podejścia do prawa Cycerona i Ulpiana zob. O. Tellegen-Couperus, Cicero and Ulpian, Two Paragons of Legal Practice, "Revue Internationale des Droits de l'Antiquité" 2008, tome LV, s. 485-497.

${ }^{43}$ W. Litewski, Jurysprudencja, s. 135-155. 
wiedzę prawniczą i obaj z różnych względów, także charakterologicznych, zrezygnowali $z$ tej ścieżki zawodowej na rzecz polityki i filozofii. O ile jednak we współczesnych realiach nie mamy wątpliwości, iż Radruch „był nie tylko, lecz także prawnikiem”, o tyle w realiach rzymskich można całkiem zasadnie stawiać znane nam już pytanie: „Cyceron był z pewnością filozofem, retorem i politykiem, ale czy był także prawnikiem?”.

Kilkadziesiąt lat temu adwokat Roman Łyczywek opublikował na łamach „Palestry” artykuł Marek T. Cyceron - adwokat rzymskit ${ }^{44}$ Ten bardzo interesujący i pełen historycznej erudycji tekst był jednak chyba nieco mylący, ponieważ mógł ostatecznie sugerować daleko idące podobieństwo pomiędzy współczesnym adwokatem i rzymskim advocatus. Przyjrzyjmy się więc nieco bliżej temu, co na temat rzymskiego pojęcia advocatus piszą współcześni romaniści, ponieważ ich głos w perspektywie historycznej wydaje się mieć znaczenie decydujące. Wprawdzie ta instytucja podlegała pewnej ewolucji - od republiki przez pryncypat i dominat aż po średniowiecze - to jednak nas interesuje tutaj szczególnie okres późnorepublikański, ponieważ widać wyraźnie, że bardziej liczyły się kompetencje retoryczne niż merytoryczne advocati: „W okresie prawa klasycznego advocati występowali jako mówcy sądowi, posiadający elementarne wiadomości prawnicze, szkoleni w sztuce retorycznej Greków (zwani oni byli również: oratores, patroni, causidici, rhetores). Od schyłku republiki advocati występowali jako pomocnicy stron, a ich działalność ograniczała się do wspierania stron bezpośrednio w samym procesie, w przeciwieństwie do iuris consulti udzielających porad prawnych niezależnie od toczącego się postępowania. W okresie republikańskim advocati spełniali swoje funkcje procesowe nieodpłatnie, poza wypadkami, kiedy otrzymywali dobrowolne wynagrodzenie (,,uhonorowanie za zasługi - honorarium) za świadczone usługi w formie prezentu lub zapisu testamentowego ${ }^{45}$.

44 „Palestra” 1960, nr 4/9(33), s. 75-91.

45 D. Zybała, Advocatus, w: Leksykon, s. 18; podobnie W. Rozwadowski, Advocatus, Prawo rzymskie, s. 20: „Advocatus zazwyczaj był mało obeznany z prawem, w przeciwieństwie do iuris periti". 
Cały problem sprowadza się więc zarówno do pytania o skalę i poziom wiedzy prawniczej, którą rzeczywiście mieli/powinni mieć w praktyce rzymscy advocati, jak i do pytania o pewien inny sposób myślenia, odróżniający ich od iuris periti. We współczesnej literaturze przeważa wprawdzie pogląd, iż wiedza prawnicza nie była im w jakiś szczególny sposób konieczna, ponieważ zawsze mogli udać się po radę do iuris consulti (vide: Cyceron i Piso w przywołanej już wyżej sprawie Cecyny), ale można też spotkać opinie uznające takie stanowisko za znaczne uproszczenie dosyć skomplikowanego zagadnienia $^{46}$. W literaturze polskiej Przemysław Kubiak bardzo przekonywająco dowodzi, opierając się na źródłach i nowszych badaniach, że w rzeczywistości przynajmniej czołówka iuris consulti odznaczała się wysokimi kompetencjami retorycznymi, i odwrotnie najlepsi mówcy znakomicie orientowali się w meandrach prawa, co w dużej mierze wynikało z systemu kształcenia rzymskiej młodzieży w wyższych warstwach społecznych ${ }^{47}$. Dotyczyło to w szczególności tzw. patroni.

Trzeba przyznać, że sam Cyceron nie ułatwił nam rozwiązania tego sporu, skoro sformułował następującą sentencję w dialogu O państwie: „Przed dobrym sędzią argumenty znaczą więcej niż świadkowie" (Apud bonum iudicem argumenta plus quam testes valent - De republica $1,38,59)^{48} . Z$ filozoficzno-prawnego punktu widzenia ta wypowiedź może nas nieco zaskakiwać, czy nawet szokować, ale dla Cycerona retorycznie była oczywistością. Nawet więcej - pod względem roli, jaką odgrywali w praktyce rzymscy advocati, można uznać ją za bardzo charakterystyczną. Znany i współczesny Cyceronowi iuris consultus, Gaius Aquillius Gallus (ten sam, który napisał opinię prawną w sprawie Cecyny), zapytany o znaczenie oceny faktów w pracy prawnika miał odpowiedzieć: „To

${ }^{46}$ Zob. np. A.M. Riggsby, Roman Law and the Legal World of the Romans, New York 2010, s. 49-54.

${ }^{47}$ P. Kubiak, Kilka uwag na temat znajomości prawa u mówców sądowych republikańskiego Rzymu, „Krakowskie Studia z Historii Państwa i Prawa” 2015, t. 8 , nr 1, s. 1-24.

${ }^{48}$ K. Burczak, A. Dembiński, M. Jońca, Łacińskie sentencje, s. 17. 
nie jest kwestia dla prawa, to kwestia dla Cycerona" (Nihil hoc ad ius, ad Ciceronem $)^{49}$.

Spójrzmy teraz na ten sam problem $z$ nieco szerszej, współczesnej perspektywy - najnowsze badania próbują bowiem dokonać istotnej weryfikacji pewnej ugruntowanej i bardzo krytycznej tezy romanistów o Cyceronie jako prawniku. Szczególnie charakterystyczna była pod tym względem opinia amerykańskiego uczonego Alana Watsona, autora znanej pracy The Spirit of Roman Law ${ }^{50}-$ w jej świetle Cyceron był na tle rzymskiej jurysprudencji po prostu outsiderem $^{51}$. To dosyć wąskie spojrzenie na Cycerona $z$ perspektywy dogmatyki rzymskiego prawa prywatnego ostatnio z kolei zakwestionowali autorzy zbiorowego opracowania Cicero's Law. Rethinking Roman Law of the Late Republic ${ }^{52}$. Rzeczywiście, jeśli spojrzeć na problem z szerszej perspektywy filozoficzno- i polityczno-prawnej, to okazuje się, że rzecz istotnie wymaga ponownego przemyślenia i że prawnikiem Cyceron jednak był, i to wcale nie w roli outsidera, nawet jeśli nie pełnił funkcji klasycznego rzymskiego jurysty.

We współczesnej nauce prawa mamy do czynienia ze zmianą znaczenia dotychczasowych pojęć. Przy okazji okazuje się, że dokonane wyżej porównanie Radbrucha i Cycerona nie jest aż tak bezzasadne, jakby z pozoru mogło się wydawać. Brytyjski socjolog prawa Roger Cotterrell wyjaśnia bowiem na przykładzie Radbrucha, na czym polega różnica pomiędzy prawnikiem w znaczeniu jurist i prawnikiem w znaczeniu lawyer ${ }^{53}$. Temu pierwszemu towarzyszy głębokie poczucie profesjonalnej odpowiedzialności za prawo i w związku $z$ tym nie jest mu obojętne, ani to, jak prawo jest tworzone, ani to, jaką ma treść; ten drugi z kolei koncentruje się prawie wyłącznie na warsztatowych aspektach procesu stosowania prawa

49 A.M. Riggsby, Roman Law, s. 47; szczegółowo o szerszym filozoficzno-prawnym znaczeniu tej frazy O. E. Tellegen-Couperus, J. W. Tellegen, Nihil hoc ad ius, ad Ciceronem, "Revue Internationale des Droits de l'Antiquité" 2006, vol. 3, s. 381-408.

50 Athens (Georgia) 1995.

51 Ibidem, s. 195 i n.

${ }^{52}$ Zob. wyżej przyp. 28.

${ }^{53}$ R. Cotterrell, The Role of the Jurist: Reflections around Radbruch, "Ratio Juris" 2013, vol. 26, issue 4, s. 510-522. 
i jego wykładni. Gdyby przyłożyć tę terminologię do opisanych wyżej realiów rzymskiej jurysprudencji, to paradoksalnie zmieniają się nam znaczenia - okazuje się bowiem, że to Cyceron byłby uznany za jurist, natomiast klasycznych rzymskich prawników trzeba by opatrywać terminem lawyers.

Czytelników zainteresowanych nie naukową, lecz raczej zbeletryzowaną historią ostatnich lat rzymskiej republiki widzianej przez pryzmat biografii Cycerona można odesłać do wydanej ostatnio trylogii rzymskiej R. Harrisa. W trzecim tomie Dyktator ${ }^{54}$ autor wkłada w usta bohatera słowa $z$ jego ostatniej przed upadkiem republiki mowy w rzymskim senacie. Cyceron przyznaje samokrytycznie, że pozwalając w przeszłości na odstępstwa od prawa, sam przyczynił się do klęski: „Za każdym razem [...], kiedy ulegaliśmy pokusie i ignorowaliśmy prawo, często - jak się nam wydawało - ze słusznych powodów, posuwaliśmy się o krok w kierunku przepaści”. Ale ostatecznie wypowiada następujące, chociaż już spóźnione słowa: „Republika rzymska, ze swoim podziałem władzy, ze swoimi corocznymi wolnymi wyborami na każdy urząd publiczny, ze swoimi sądami i ławami przysięgłych, $z$ równowagą sił pomiędzy senatem i ludem, $z$ wolnością słowa i myśli, jest najszlachetniejszym dziełem rodzaju ludzkiego. I prędzej legnę na ziemi, krztusząc się własną krwią, aniżeli zdradzę zasadę, na której to wszystko się opiera, a która polega na bezwzględnym prymacie rządów prawa”.

Czy więc Cycero był prawnikiem? Zdecydowanie tak, tyle że jego rozumienie prawa i prawoznawstwa być może wyrosło nieco ponad epokę, w której przyszło mu żyć. Jeśli jego słowa $z$ oratio pro Murena pozbawimy oczywistego kontekstu sytuacyjnego i nieco odrzemy $z$ nadmiernej ironii i kpiny, a następnie poddamy racjonalnej współczesnej interpretacji (czy nawet uprawnionej w tym przypadku - nadinterpretacji), to może się okazać, że Cyceron chciał powiedzieć nam coś ważnego: po pierwsze, że prawo nie jest tylko kartką papieru zapisaną konwencjonalnymi formułami; po drugie, że rola prawnika nie może polegać wyłącznie na mechanicznym i bezrefleksyjnym, mniej lub bardziej twórczym, odtwarzaniu tych

54 Warszawa 2018, s. 442 i n. 
formuł; po trzecie wreszcie, że w pracy prawnika nie liczy się tylko jego wiedza o prawie, lecz także biegłość argumentacyjna.

Nasuwa się nam tutaj pewna refleksja na tle książki słynnego amerykańskiego filozofa prawa Ronalda Dworkina, Justice for Hedgehogs (Sprawiedliwość według jeży) ${ }^{55}$. Jej tytuł nawiązuje do znanego eseju Isaiaha Berlina i podziału uczonych na jeże i lisy: „Wśród fragmentów greckiego poety Archilocha jest wers, który brzmi: "Lis wie wiele rzeczy, ale jeż jedną niemałą". Uczeni różnie interpretowali te niejasne słowa, które zapewne znaczą tylko tyle, że lis, przy całej swojej przebiegłości, musi skapitulować przed jedną bronią jeża. Słowa te rozumiane przenośnie mogą jednak ujawnić sens uwypuklający jedną z najgłębszych różnic, jakie dzielą pisarzy i myślicieli, a być może ludzi w ogóle. Istnieje bowiem ogromna przepaść między tymi, którzy sprowadzają wszystko do jednej centralnej wizji, jednego mniej lub bardziej spójnego czy artykułowanego systemu, w którego ramach rozumieją, myślą i czują - do jednej, powszechnej, organizującej zasady, dzięki której wszystko, czym są i co mówią, ma znaczenie - a z drugiej strony tymi, którzy zmierzają do rozlicznych celów, często niezwiązanych, a nawet sprzecznych ze sobą, a jeśli w ogóle jakoś pokrewnych, to tylko jakby de facto, z pewnych psychologicznych czy fizjologicznych przyczyn, niepowiązanych żadną zasadą moralną lub estetyczną; żywot, jaki pędzą ci ostatni, czyny, których dokonują, idee, którym hołdują, można określić raczej jako odśrodkowe niż dośrodkowe, ich myśl rozprasza się, czy też rozpływa, błądzi na wielu poziomach, chwytając istotę najprzeróżniejszych doświadczeń i rzeczy jako coś, czym są same w sobie, i nie starając się, świadomie czy nieświadomie, umieścić ich w obrębie - lub pozostawić poza obrębem - jakiejś jednej niezmiennej, wszechogarniającej, czasem wewnętrznie sprzecznej i niepełnej, niekiedy fantastycznej, jednolitej perspektywy wewnętrznej. Pierwszy typ intelektualno-artystycznej osobowości zalicza się do jeży, drugi do lisów [...]"56.

55 Cambridge (Mass.)-London 2011.

${ }^{56}$ I. Berlin, Jeż $i$ lis, tłum. A. Komarek, H. Krzeczkowski, K. Tarnowska, Warszawa 1993, s. 27 i n. 
Cyceron w swoim stosunku do prawa przyjmował zdecydowanie bardziej postawę widzącego całość jeża niż gubiącego się w szczegółach lisa. A może inaczej - na początku swojej kariery odgrywał gównie rolę biegłego w retoryce lisa, u schyłku życia był raczej jeżem poszukującym filozoficznych podstaw państwa i prawa ${ }^{57}$. Warto więc spojrzeć na ten problem $z$ punktu widzenia współczesnych sporów o status metodologiczny jurysprudencji (prawoznawstwa/nauk prawnych) ${ }^{58}$. Rzymscy juryści uchodzą bowiem, obok klasycznych pozytywistów prawniczych, za typowy przykład autonomii metodologicznej prawoznawstwa jako pewnego zamkniętego systemu myślowego, dosyć hermetycznie oddzielonego od innych dziedzin wiedzy. Tymczasem współcześnie poszukuje się takiego modelu, który otworzy maksymalnie prawoznawstwo na inne nauki, ale bez jednoczesnego utracenia pewnej względnej autonomii wynikającej ze specyfiki fenomenu prawa. Niektórzy mogą to potraktować jako tezę zbyt daleko idącą w swoim ahistoryzmie, ale mimo wszystko zaryzykuję - Cyceronowi z całą pewnością byłoby bliżej do tego nowoczesnego modelu prawoznawstwa niż do tradycyjnej autonomicznej wizji prawnika.

Swoje rozważania filozoficzno-prawne Cyceron sytuuje przede wszystkim na poziomie makro, a więc systemu polityczno-prawnego jako całości, jurysprudencja rzymska z kolei operowała głównie na poziomie konkretnych przypadków dogmatycznych, a więc w skali mikro. Pierwsza prawdziwa, pomijając pewne wcześniejsze próby jeszcze z okresu późnorepublikańskiego, synteza tej kazuistyki pojawia się dopiero w okresie klasycznym w postaci Instytucji Gaiusa $^{59}$, ale trudno w tym dziele szukać imienia Cycerona ${ }^{60}$. Mamy

${ }^{57} \mathrm{~W}$ jakimś sensie charakterystyczny podtytuł nosi pod tym względem przywołana wyżej (przyp. 38) praca J. Harries, From Citizens' Law to the Lawful State.

58 J. Stelmach, B. Brożek, Metody prawnicze. Logika - analiza - argumentacja - hermeneutyka, Warszawa 2006.

59 M.H. Wibier, Transmitting Legal Knowledge: From Question-and-Answer Format to Handbook in Gaius' Institutes, w: Between Orality and Literacy: Communication and Adaptation in Antiquity, R. Scodel (ed.), Leiden 2014, s. 356-373.

${ }^{60}$ Zob. Gaius, Instytucje, przeł. C. Kunderewicz, Warszawa 1982; co jednak ciekawe, z kolei autorzy współczesnych komentarzy do Gaiusa bardzo często 
jednak dowody na to, że Cyceron w tym zakresie już ponad 100 lat wcześniej rozumował podobnie. Wprawdzie nie znamy bliżej treści jego, wspomnianego już wyżej, jedynie planowanego/zaginionego traktatu De iure civili in artem redigendo, ale pewne elementy można odnaleźć także np. w De oratore czy Topikach.

Tak czy inaczej, na przykładzie Cycerona jesteśmy w stanie przynajmniej częściowo zrekonstruować pewne infiltracje na linii prawo rzymskie (jurysprudencja) $\rightarrow$ filozofia rzymska. Znacznie trudniej zrobić to niestety w przeciwnym kierunku: filozofia rzymska $\rightarrow$ prawo rzymskie (jurysprudencja). Także w tym zakresie za pewien sztandarowy przykład może nam posłużyć Cyceron i jego dzieła, a zwłaszcza jego mowy procesowe. Współczesnych romanistów ciągle pasjonuje bowiem następujące pytanie: jak liczne są cytowania Cycerona przez rzymskich prawników w Digestach i jakie znaczenie miały dla nich te odwołania w zakresie rozumienia konkretnych instytucji prawnych, a więc nie na poziomie filozofii prawa, lecz raczej dogmatyki prawa cywilnego? Inny słowy - czy Cyceron był dla rzymskich jurystów jakimkolwiek prawniczym autorytetem i czy w ogóle uważali go za prawnika? Odpowiedzi na te pytania nie są jednoznaczne - według jednych badaczy to znaczenie było raczej marginalne ${ }^{61}$, inni skłonni są mu przypisywać nieco większą rolę $^{62}$. Rzeczywiście, trzeba przyznać, że jak na wręcz legendarną sławę Cycerona jego cytowania w Digestach są stosunkowo nieliczne i najczęściej dotyczą stanowiska w sprawie tej czy innej instytucji prawnej wyrażonego w mowach sądowych, nie ma natomiast jakiegoś szerszego odwołania do jego pism filozoficznych. To jednak jest zrozumiałe $z$ uwagi zarówno na charakter aktywności klasycznych rzymskich prawników, jak i charakter samych Digestów.

odwołują się do Arpinaty, tłumacząc poszczególne punkty Instytucji (zob. np Gai Institutiones or Institutes of Romas Law by Gaius, transl. and commentary E. Poste, historical introduction A.H.J. Greenidge, Oxford 1904).

${ }^{61}$ Tak np. D. Nörr, Cicero-Zitate bei den klassischen Juristen. Zur Bedeutung literarischer Zitate bei den Juristen und zur Wirkungsgechichte Ciceros, Ciceroniana. Atti del III Colloquium Tullianum, Roma 1978, s. 111-150.

${ }^{62}$ Tak np. M. Wibier, Cicero's Reception in the Juristic Tradition of the Early Empire, w: Cicero's Law, s. 100-122. 
Nie rozstrzygniemy tutaj tego problemu. Możemy tylko powiedzieć, że opinia o Cyceronie w oczach pisarzy okresu klasycznego była w głównej mierze kształtowana na linii retoryka-jurysprudencja. To, że Cyceron miał stosunkowo niewielki wpływ na klasyczną rzymską jurysprudencję, nie oznacza oczywiście, iż był nieobecny także w innych dziedzinach - przeciwnie, jego recepcja w okresie wczesnego cesarstwa była bardzo szeroka, zwłaszcza w sferze edukacji retorycznej ${ }^{63}$. Stąd np. Kwintylian w Institutionis oratoriae libri XII stawia Cycerona za wzór nie tylko retora, ale i prawnika, chociaż jednocześnie $z$ oczywistych względów tak jak Cyceron podporządkowuje jurysprudencję retoryce. Ale już np. Pomponius, kreśląc w Enchiridion krótką historię rzymskiej jurysprudencji, dosyć stanowczo deprecjonuje Cycerona jako prawnika i chyba także filozofa, skoro na pierwszy plan w zakresie filozofii prawa wysuwa postać Marcusa Antistiusa Labeo ${ }^{64}$.

Cyceron jako filozof i prawnik doczekał się jednak swojej wielkiej chwili w epoce humanizmu - autor współczesnej monografii na temat historii prawników rozdział poświęcony temu okresowi zatytułował w bardzo charakterystyczny sposób, tak jak brzmiał tytuł wspomnianego już nieznanego nam bliżej traktatu: De Iure Civile in Artem Redigendo: The Humanist Ideal ${ }^{65}$. Może jednak właśnie na tym polega rola filozofii prawa w funkcjonowaniu systemu prawa i w wykonywaniu zawodu prawnika. Chodzi w niej nie tyle o bezpośrednią ingerencję w kazuistykę i ocenę konkretnych stanów faktycznych czy instytucji prawnych, ile o wyznaczenie pewnej perspektywy spojrzenia na oba te fenomeny niejako „z lotu ptaka”. Wydaje się, że taki jest też sens i podstawowa rola słynnych sentencji etyczno-prawnych ${ }^{66}$, także tych umieszczonych na budynku Sądu Najwyższego - w procesie wykładni mogą nam pozwolić na

${ }^{63}$ Zob. T.J. Keeline, The Reception of Cicero in the Early Roman Empire. The Rhetorical Schoolroom and the Creation of a Cultural Legend, Cambridge 2018.

${ }^{64}$ M. Wibier, Cicero's Reception, s. 111 i 119.

65 J. Gordley, The Jurists. A Critical History, Oxford 2013, s. 111-140.

66 T. Nótári, On the Role of Ethical Maxims in the System of Classical Interpretation of Law, w: Is A Universal Morality Possible?, F. Hörcher, B. Mester, Z. Turgonyi (ed.), Budapest 2015, s. 83-93. 
krytyczne spojrzenie $z$ punktu widzenia systemu prawa jako całości i z punktu widzenia innych systemów normatywnych otaczających system prawa.

\section{STRESZCZENIE}

Rzym, filozofia, prawo

Głównym celem artykułu jest odpowiedź na następujące pytanie: jaka była relacja pomiędzy filozofią grecką i prawem rzymskim? Na tym tle autor stawia kolejne pytanie: czy Cyceron był prawnikiem? Przez wiele lat problem ten był przedmiotem kontrowersji pomiędzy romanistami, historykami oraz teoretykami retoryki. Autor stawia dwie hipotezy - historyczną i współczesną. W świetle pierwszej Cyceron nie był jurystą, ponieważ przed sądem występował jako adwokat, a nie jako juris consultus. $Z$ kolei w perspektywie współczesnej sprawa jest bardziej skomplikowana - był prawnikiem (jurist) we współczesnym sensie, nawet jeśli w tym samym sensie nie był prawnikiem rozumianym jako lawyer.

Słowa kluczowe: filozofia grecka; prawo rzymskie; wpływy; relacje; Cyceron

\section{SUMMARY}

Rome, philosophy, law

The main purpose of this article is the answer to the following question: what was the relation between Greek philosophy and Roman law? On this background, the author puts the next question: was Cicero the jurist or not? This problem was controversial for many years between romanists, historians and theoreticians of rhetoric as well. The author puts two hypothesis - firstly, the historical one and secondly, the modern one. In the light of the first Cicero was not the jurist, because he played in the court the role of Roman advocatus and not the Roman iuris consultus. From the modern perspective is the problem more complicated - he was the jursit in modern sense, even if he was not the lawyer in today's meaning.

Keywords: Greek philosophy; Roman law; influences; relations; Cicero 


\section{BIBLIOGRAFIA}

Algra K., Barnes J., Mansfeld J., Schofield M. (ed.), The Cambridge History of Hellenistic Philosophy, Cambridge 1999.

Berlin I., Jeż i lis, tłum. A. Komarek, H. Krzeczkowski, K. Tarnowska, Warszawa 1993.

Burczak K., Dembiński A., Jońca M., Łacińskie sentencje i powiedzenia prawnicze, Warszawa 2018.

Cotterrell R., The Role of the Jurist: Reflections around Radbruch, "Ratio Juris" 2013, vol. 26, issue 4,

Crook J.A., Legal Advocacy in the Roman World, Ithaca-New York 1995.

Cyceron, Mowy, tłum. S. Kołodziejczyk, Z. Mrukówna, D. Turkowska, Kęty 2003.

Gai Institutiones or Institutes of Romas Law by Gaius, transl. and commentary E. Poste, historical introduction A.H.J. Greenidge, Oxford 1904.

Gaius, Instytucje, przeł. C. Kunderewicz, Warszawa 1982.

Gordley J., The Jurists. A Critical History, Oxford 2013.

Griffin M.T., Latin philosophy and Roman law, w: Politeia in Greek and Roman Philosophy, V. Harte, M. Lane (ed.), Cambridge 2013.

Waśkiewicz H., „De legibus” Cicerona - pierwszy $w$ dziejach myśli europejskiej system filozoficzno-prawny, „Roczniki Filozoficzne” KUL 1960, t. 8, nr 2 .

Harries J., Cicero and the Jurists. From Citizens' Law to the Lawful State, London 2006.

Harries J., The law in Cicero's writings, w: The Cambridge Companion to Cicero, C. Steel (ed.), Cambridge 2013.

Honoré T., Ulpian. Pioneer of Human Rights, Oxford 2002.

Honsell H., Mayer-Maly Th., Rechtswissenschaft. Eine Einführung in das Recht und seine Grundlagen, Berlin-Heidelberg 2015.

Kamiński J., Cicero, w: Prawo rzymskie. Słownik encyklopedyczny, red. W. Wołodkiewicz, Warszawa 1986.

Keeline T.J., The Reception of Cicero in the Early Roman Empire. The Rhetorical Schoolroom and the Creation of a Cultural Legend, Cambridge 2018.

Koschenbahr-Łyskowski J., Ratio naturalis $w$ prawie rzymskiem klasycznem, Warszawa 1930.

Kroger J.R., The Philosophical Foundations of Roman Law: Aristotle, the Stoics, and Roman Theories of Natural Law, "Wisconsin Law Review" 2004.

Kubiak P., Kilka uwag na temat znajomości prawa u mówców sądowych republikańskiego Rzymu, „Krakowskie Studia z Historii Państwa i Prawa” 2015, t. 8, nr 1.

Kumaniecki K., Literatura rzymska. Okres cyceroński, Warszawa 1977. 
Litewski W., Jurysprudencja rzymska, Kraków 2000.

Litewski W., Podstawowe wartości prawa rzymskiego, Kraków 2001.

Llano Alonso F.H., Cicero and Natural Law, "Archiv für Rechts- und Sozialphilosophie" 2012, vol. 98, no. 2.

Lučić Z., Cicero als Jurist und Theoretiker, "Annales FLB - Belgrad Law Review" 2010, year LVIII, no. 3.

Michalunio SJ Cz., Dicta editio maior. Zbiór łacińskich sentencji, przysłów, zwrotów, powiedzeń, Kraków 2008.

Müller G.M., Zini F.M. (Hrsg.), Philosophie in Rom - Römische Philosophie? Kultur-, literatur- und philosophiegeschichtliche Perspektiven, Berlin-Boston 2018.

Nörr D., Cicero-Zitate bei den klassischen Juristen. Zur Bedeutung literarischer Zitate bei den Juristen und zur Wirkungsgechichte Ciceros, Ciceroniana. Atti del III Colloquium Tullianum, Roma 1978.

Nótári T., On the Role of Ethical Maxims in the System of Classical Interpretation of Law, w: Is A Universal Morality Possible?, F. Hörcher, B. Mester, Z. Turgonyi (ed.), Budapest 2015.

Pikuła Ł., Iurisprudentia, w: Leksykon tradycji rzymskiego prawa prywatnego, red. A. Debiński, M. Jońca, Warszawa 2016.

Plessis P.J. du (ed.), Cicero's Law. Rethinking Roman Law of the Late Republic, Edinburgh 2016.

Powell J.G.E. (ed.), Cicero: The Philosopher. Twelve Papers, New York 1995 (reprinted 2002).

Riggsby M., Roman Law and the Legal World of the Romans, New York 2010.

Stelmach J., Brożek B., Metody prawnicze. Logika - analiza - argumentacja - hermeneutyka, Warszawa 2006.

Tarwacka A., O sprawiedliwości i prawie. 1 tytuł 1 księgi Digestów. Tekst ttumaczenie - komentarz, „Zeszyty Prawnicze UKSW” 2003, t. 3, nr 2.

Taylor H., Taylor Hunt M.L., The Sayings of Cicero, w: H. Taylor, Cicero. A Sketch of His Life and Works, Chicago 1916.

Tellegen-Couperus O., Cicero and Ulpian, Two Paragons of Legal Practice, "Revue Internationale des Droits de l'Antiquité" 2008, t. LV.

Vander Waerdt P.A., Philosophical Influence on Roman Jurisprudence? The Case of Stoicism and Natural Law, w: Aufstieg und Niedergang der römischen Welt, Teil II, Band 36, Teilband 6, Walter De Gruyter, Berlin-New York 1992.

Stroh W., Cicero. Redner, Staatsmann, Philosoph, München 2008.

Wibier M.H., Transmitting Legal Knowledge: From Question-and-Answer Format to Handbook in Gaius' Institutes, w: Between Orality and Literacy: Communication and Adaptation in Antiquity, R. Scodel (ed.), Leiden 2014.

Wołodkiewicz W. (red.), Regulae iuris. Łacinskie inskrypcje na kolumnach Sądu Najwyższego Rzeczypospolitej Polskiej, Warszawa 2010. 
Woolf R., Cicero. The Philosophy of a Roman Sceptic, London-New York 2015. Zajadło J., Czesław Znamierowski - uczony transcendentny, „Państwo i Prawo" 2018, nr 11.

Zajadło J., Czy Cyceron byt prawnikiem?, „Palestra” 2018, nr 11.

Zajadło J., Dziedzictwo przeszłości. Gustaw Radbruch: portret filozofa, prawnika, polityka i humanisty, Gdańsk 2007.

Zieliński T., Cicero im Wandel der Jahrhunderte, Wiesbaden 1912.

Zyl D.H. van, Cicero's Eclecticism and Orgiinality, "Akroterion - Journal for the Classics in South Africa” 1990, vol. 35, vo. 3-4. 